\title{
Preliminary Map Showing Quaternary Geology of the Mooresville East 7.5-Minute Quadrangle, Indiana
}
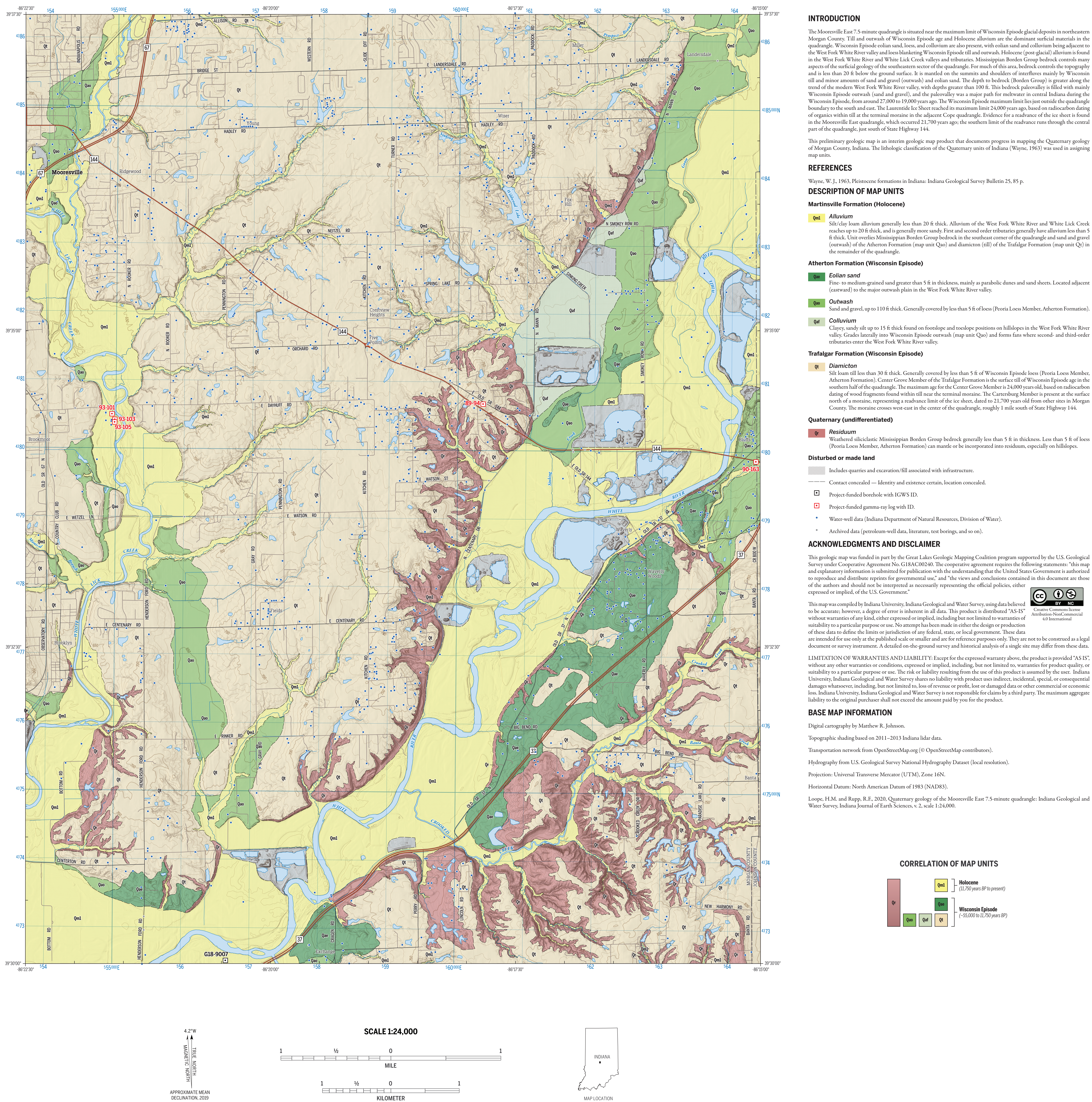